\title{
Gastronomi ve Mutfak Sanatları Eğitiminde İstihdam Yapısına İlişkin Bir Araştırma
}

\author{
Serkan SEMINTT ${ }^{1}$ ve Gülçin ÖZBAY ${ }^{2}$
}

$\ddot{O} z$

Gastronomi ve mutfak sanatları eğitimininde verimliliği ve kaliteyi arttırmak için bazı gereksinimler ortaya çıkmaktadır. Bu gereksinimler verilen uygulamalı eğitimin durumuna göre şekillenmektedir. Ĕ̆itimde kaliteyi arttırmak ve eğitimin niteliğini korumak için bu ihtiyaçlar önem arz etmektedir. İhtiyaçlardan biri de donanımlı öğretim elemanlarıdır. Bu bağlamda Türkiye'de lisans düzeyinde gastronomi ve mutfak sanatları eğitimi veren kurumlardaki öğretim üyelerinin niteliksel ve niceliksel açıdan incelenmesi temel amaç olarak belirlenmiştir. Bu amaç doğrultusunda nitel araştırma yöntemlerinden yarı yapılandırılmış görüşme tekniği kullanılmıştır. Katılımcılara iki adet açık uçlu soru yöneltilmiştir. Araştırma için Türkiye'de aktif bir şekilde gastronomi ve mutfak sanatları eğitimi veren 68 kurumda istihdam edilen bölüm başkanlarına ulaşılmaya çalışılmıştır. Bu kurumlar içerisinden 38 bölüm başkanı ile mülakat yapılmıştır. Elde edilen bilgiler doğrultusunda temalar oluşturulmuş, amaca uygun olacak şekilde yorumlanmış ve katılımcılardan alınan bulgular analiz edilmiştir. Gastronomi ve mutfak sanatları eğitiminde istihdam edilen 406 öğretim üyesinin lisans mezuniyet alanları araştırılarak çalışma desteklenmiştir. Araştırma sonucuna göre Türkiye'de gastronomi ve mutfak sanatları eğitiminde istihdam edilen öğretim üyelerinin 46 farklı alandan mezun olduğu ve genele bakıldığında bu alanlar içerisinde gastronomi mezuniyetine sahip kişilerin sadece \%14'lük bir paya sahip olduğu sonucuna ulaşılmıştır. Elde edilen sonuç doğrultusunda gastronomi eğitiminin fiziki olanağına, akademik yapısına ve akademik üyelerin niteliğine, niceliğine yönelik öneriler sunulmuştur.

Anabtar Kelimeler: Eğitim, Gastronomi, Gastronomi ve Mutfak Sanatları, Türkiye

\section{A Research on the Employment Structure in the Education of Gastronomy and Culinary} Arts

\section{Abstract}

Some requirements arise in order to increase efficiency and quality in gastronomy and culinary arts education. These requirements are shaped according to the state of applied education. These needs are important in order to increase the quality of education and to protect the quality of education. One of the needs is well-equipped teaching staff. Investigation of the qualitative and quantitative terms in this context, Turkey gastronomy and culinary arts education at the undergraduate level in academic institutions has been identified as the main objective. For this purpose, semi-structured interview technique, one of the qualitative research methods, was used. Two open-ended questions were asked to the participants. Research in an active way in Turkey for gastronomy and culinary arts education organization that has tried to reach the 68 department heads are employed. Among these institutions, 38 department heads were interviewed. In line with the information obtained, themes were created, interpreted in accordance with the purpose, and the findings from the participants were analyzed. The study was supported by researching the undergraduate graduation areas of 406 faculty members employed in gastronomy and culinary arts education. According to the research concluded that in Turkey in gastronomy and culinary arts training of employed faculty members 46 have graduated from different areas and when viewed overall with graduation gastronomy in these areas people only have reached the conclusion that it has a share of $14 \%$. In line with the obtained results, suggestions were made regarding the physical facilities, academic structure, quality and quantity of the academic members of gastronomy education.

Key Words: Education, Gastronomy, Gastronomy and Culinary Arts, Turkey

\author{
Atıf İçin / Please Cite As: \\ Semint, S., Özbay, G. (2021). Gastronomi ve Mutfak Sanatları Eğitiminde İstihdam Yapısına İlişkin Bir Araştırma. \\ Manas Sosyal Arastirmalar Dergisi, 10(3), 2060-2075.
}

Geliş Tarihi / Received Date: 20.02.2021

Kabul Tarihi / Accepted Date: 04.04.2021

Bu çalışma, Serkan SEMINTT tarafından "Türkiye'de Gastronomi ve Mutfak Sanatları Eğitiminin Temel Sorunları Üzerine Bir Araştırma " adlı yüksek lisans tezinden türetilmiştir.

${ }^{1}$ Bilim Uzmanı - Sakarya Uygulamalı Bilimler Üniversitesi, Lisansüstü Eğitim Enstitüsü, Turizm İşletmeciliği-

semintserkann@gmail.com - iD ORCID: 0000-0002-6305-1898

${ }^{2}$ Dr. Öğr. Üyesi - Sakarya Uygulamalı Bilimler Üniversitesi, Turizm Fakültesi, Gastronomi ve Mutfak Sanatlar1-

gozbay@subu.edu.tr - (iD ORCID: 0000-0002-5647-7137 


\section{Giriş}

Yiyecek içecek olgusu temel bir ihtiyaçtır ve bu ihtiyacı karşılamada yiyecek içecek endüstrisinin önemli bir katkısı bulunmaktadır. Kişilerin yemek ihtiyaçlarını karşılama görevini üstlenen yiyecek içecek işletmeleri en kaliteli şekilde bu hizmeti yerine getirmek durumundadır. İşletmeler kaliteli hizmet sunabilmek için eğitimli personele ihtiyaç duymaktadır. Çünkü ancak alanında donanımlı, nitelikli, analitik düşünebilen personel işletmelere verimlilik ve sürdürülebilirlik sağlamaktadır. Günümüzde yiyecek içecek kavramları gastronomi alanında kendini göstermektedir. Bu nedenle gastronomi ve mutfak sanatları bölümü adı altında birçok üniversite eğitim vermektedir. Yiyecek içecek endüstrisi için önemli olan insan gücünün niteliği, bilgisi ve donanımı gastronomi eğitimiyle karşılanmaktadır.

Amerika Birleşik Devletleri ve Fransa, İtalya, İngiltere gibi ülkelerde yüzylllar önce sektörün ihtiyaçlarını karşılamak için kurumsallaşmış kurslar başlatılmış ve okullar kurulmuştur. Bu okullar yiyecek içecek sektörü için nitelikli ve donanımlı personel yetiştirmede önemli katkı sağlamaktadır. Bünyesinde bulunan gastronomik ürünleri tüm dünyaya pazarlayabilen İspanya, İtalya, Fransa gibi ülkelerde gastronomi eğitiminin önemi giderek artmaktadır (Aydemir, 2018, ss. 22-23).

Türkiye'de aşçıllk eğitiminin kökeni ahilik kültüründen gelen usta çırak ilişkisine dayanmaktadır. Cumhuriyetin ilk yıllarında okul çağına gelene kadar açılan kurslar, eğitimin temelini oluşturmaktadır (Kurnaz, Babür ve Kurnaz, 2018, s. 507). 1950’li yıllara kadar aşçı yetiştirilmesi usta çırak yöntemi ile olmuş, bu yıllardan itibaren Ankara, İzmir ve İstanbul'da Belediyeler ve Meslek Odaları bünyesinde kısa süreli kurslar ile aş̧̧lar yetiştirilmeye başlanmıştır (Öztürk ve Görkem, 2011, s. 71; Görkem ve Sevim, 2016, s. 979). 1961-1962 öğretim yıllarında örgün eğitim, Ankara Otelcilik Okulu’nun açılmasıyla birlikte verilmeye başlanmıştır. Bir yıllık otel yönetimi ve eğitimi ile ilgili bilgiler vermek üzere açılan okul, 19631964 yıllarında üç yıllık eğitim öğretim verilen şekle dönüşerek otelcilik okulu adını alarak eğitim vermeye devam etmiştir (Görkem ve Sevim, 2016, s. 979).

Türkiye'de gastronomi ve mutfak sanatları eğitiminin günümüzde nasıl bir durumda olduğunu ortaya koymak ve gelecekte verilecek olan gastronomi ve mutfak sanatları eğitiminin şekillenmesinde ön fizibilite olarak bu çalışma önem arz etmektedir. Bu önem doğrultusunda çalışmanın amacına uygun temalaştırmalar yapılmış ve yorumlanmıştır. Araştırmayı desteklemek için Türkiye'de gastronomi ve mutfak sanatları eğitiminde istihdam edilen öğretim üyelerinin istatistikî verileri de araştırılmıştır. Öğretim üyeleri ile de görüşmeler sağlanarak amaca yönelik yorumlar geliştirilmiştir. Yapılan bu çalışma, gastronomi alanında istihdamı yapılacak olan öğretim üyelerini belirlemek açısından son derece önemlidir. Gelecek yllarda verilecek gastronomi ve mutfak sanatları eğitiminin kalitesini artırmak ve daha verimli bir eğitim politikası oluşturmak için elde edilen sonuçlardan yararlanılabilir.

Çalışmada ilk olarak gastronomi ve mutfak sanatları eğitiminin tarihsel gelişimi hakkında kavramsal bilgilere yer verilmiştir. Araştırma bulguları ise iki ana başlık altında incelenmiştir. Birinci başlıkta literatürden elde edilen bulgulara yer verilmiştir. İçerik olarak birinci başlık gastronomi ve mutfak sanatları alanında istihdam edilen akademisyenlerin sayısal verileri ve eğitim geçmişleri hakkındaki bilgileri kapsarken ikinci başlık ise katılımcılardan alınan bulguları kapsamaktadır.

\section{Kavramsal Çerçeve}

\section{Gastronomi Eğitimi}

Aşçıllk İngiltere'de bir sanat olarak kabul edilmiş ve yemeğin miktarından çok görünümüne ve şekline önem verilmiştir. 1765 yllında modern anlamda ilk restoran Paris'te açılmıştır. Fransız ihtilalinden sonra işsiz kalmış olan saray aşçıları başta Paris olmak üzere ülkenin diğer şehirlerinde de restoran açmıştır. Bu döneme kadar olan sürede diğer meslek dallarında olduğu gibi aşçılar, usta çırak ilişskisi içerisinde mesleği öğrenmiştir. Geçmişe bakıldığında mutfak hizmeti alanlarında baskıcı bir tavır içerisinde olan şeflerin mesleki bilgi ve becerilerini astlarından sakladıkları görülmektedir. Ancak yıllar boyu sürecek bu mesleki eğitimi, mutfak eğitimini veren okullarda, yiyecek içecek işletmelerinin ihtiyacı doğrultusunda kısa sürede eğitim vermektedir. Mutfak eğitimini veren kurumlar sadece donanımlı ve nitelikli aşçılar yetiştirmenin yanında halkın gözünde yemek pişirmenin meslek olarak kabul edilmesine de katkı sağlamıştır (Öztürk ve Görkem, 2011, s. 71).

Gastronomi eğitiminin geçmişi Antik Yunan ve Roma dönemine kadar uzamaktadır. Bu dönemlerde gastronomi eğitimi veren kurumların varlığından da bahsedilmektedir. 1. yüzyılda gastronomi ile ilgili 
bilinen ilk kitabın yazıldığı ifade edilmektedir. Fakat gastronomi eğitimi tam anlamıyla 18. yüzyılda kendini göstermeye başlamıştır. İlk olarak 18. yüzyılda İngiltere de aşçllık kursu açılmış, ardından da 19. yüzyılda Amerika ve Fransa'da açılan kurslar, İngiltere'de açılan kursu takip etmiştir. 1895 yılında açılan Le Gordon Bleu ve 1922 yılından beri aşçllk eğitimi veren Cornell üniversitesi ilk mezun veren üniversiteler arasında yerini almıştır (Deveci, Deveci, Aymankuy ve Aymankuy 2020, s. 2509). Bologna, Boston ve Adelaide Üniversiteleri'nde gastronomiyi kültür ve beslenme yönüyle ele alan yüksek lisans programları, 1996 yllında ise New York Üniversitesi’nde doktora programı bu gelişim süreçlerini devam ettirme yoluna gitmiştir (Demirci, Sar1kaya ve Erol, 2020, s. 3313).

1985 yılında Milli Eğitim Bakanlığı Ticaret ve Turizm Öğretimi Genel Müdürlüğü’ne bağlı olarak açılan Mengen Aşçllık Meslek Lisesi, Türkiye'de aşçllık eğitimini lise düzeyinde veren ilk kurum olma özelliğini taşımaktadır. 2002 yılında Milli Eğitim Bakanlığı'nın okullarda isim düzenlemesi faaliyetine gitmesi sebebiyle Anadolu Otelcilik ve Turizm Meslek Liseleri bünyesine girmiştir. Fakat ilk aşçllık lisesi olma özelliğini taşıdığı için isminin başına "aşçılar” kelimesi eklenerek Mengen Aşçılar Anadolu Otelcilik ve Turizm Meslek Lisesi olarak değiştirilmiştir. 1997 yllında Abant İzzet Baysal Üniversitesi bünyesinde Türkiye'deki ilk ön lisans aşçllık programı açılmıştır (Arslanhan, 2019, s. 41; Aksoy ve Şahin, 2017, s. 8, Kurnaz vd., 2018, s. 507; Aydemir, 2018, s. 25). Sirasiyla 2001 y1linda Afyon Kocatepe Üniversitesi, 2002 yllında Anadolu Üniversitesi ve 2003 yllında ise Gaziantep Üniversitesi “Aşçlık" programlarının açılışı devam etmiştir. Vakıf üniversitesi bünyesinde ise 2006 yılında ilk olarak Kapadokya Meslek Yüksekokulu aşçılık programını açılımışır (Kurnaz vd., 2018, s. 507).

Gastronomi ve Mutfak Sanatları eğitimimi günümüzde hızlı bir artış göstermiştir. Ortaöğretim seviyesinden doktora seviyesine kadar gastronomi alanında eğitim verilmektedir. 2019 verilerine göre Türkiye'de ortaöğretim seviyesinde 534 (MEB, 2019), ön lisans seviyesinde 75, lisans seviyesinde 68 (ÖSYM 2019), yüksek lisans seviyesinde 23, doktora seviyesinde ise 5 adet kurum eğitim faaliyetlerini sürdürmektedir. Bu hızlı artışa gastronomi alanındaki popülerliğin neden olduğu düşünülmektedir.

Yükseköğretim kurumlarında verilen gastronomi eğitimlerinin yanı sıra Türkiye'de gastronomi eğitimini sağlayan özel akademiler de mevcuttur. İlk olarak İstanbul'da açllan bu akademiler İzmir ve Ankara gibi büyük şehirlerde de faaliyetlerini devam ettirmektedirler. 2000'li yılların başlarında faaliyetlerini sürdüren bu kurumlarda profesyonel aşçllk eğitimleri sekiz ile dört aylık dönemlere ayrılarak verilmektedir. Özellikle aşçllık mesleğine özel ilgisi olan personelin bu kurumları tercih ettiği bilinmektedir (Şengül, 2019, s. 173).

Türkiye'de 20. yüzyllın ikinci yarısında başlayan ortaöğretim seviyesindeki aşçllık eğitiminin, 21. yüzyllın ilk yarısında yükseköğretim düzeyinde de verildiği bilinmektedir. Zengin bir yemek kültürüne sahip olan Türkiye bu alanda eğitim faaliyetlerine geç kalmıştır. Özellikle gastronomi alanında yüksek lisans ve doktora eğitimlerine teşvik edilmesi, uzman akademisyenlerin yetiştirilmesi gastronomi eğitiminin geleceği için büyük önem arz etmektedir (Şengül, 2019, s. 173).

\section{Yöntem}

\section{Araştırmanın Amacı}

Gastronomi ve mutfak sanatları eğitiminde teorik ve uygulamaya dayalı bir eğitim modelinden yararlanılmaktadır. Bu nedenle gastronomi eğitimi almış akademik üyelerin bölümde istihdam edilmesi büyük önem arz etmektedir. Uygulamalı eğitim modelinden yararlanan gastronomi eğitimi için uygulama alanında kendini geliştirmiş nitelikli öğretim elemanlarının olması bu eğitim modeli için kaçınılmaz bir olgudur. Yapılan bu çalısma ile gastronomi alanında istihdam edilen öğretim elemanlarının mesleki özgeçmişlerini ve niteliklerini ortaya koymak, ilerleyen yıllarda istihdamı sağlanacak öğretim üyelerinin alımlarında öncül bir veri olacaktır. Bu bağlamda, Türkiye'de lisans düzeyinde gastronomi ve mutfak sanatları eğitimi veren kurumlardaki öğretim üyelerinin istatistikî verilerinin ortaya konulması ve öğretim üyelerinin lisans mezuniyetlerinin araştırılması, bu çalışmanın temel amacı olmuştur. Bununla birlikte araştırmada görüşme yapılıp bölüm başkanlarının görüşlerine de yer verilmiştir.

\section{Araştırmanın Evren ve Örneklemi}

Araştırma kapsamında gastronomi ve mutfak sanatları bölüm başkanlarının sayısının ulaşılabilir olması nedeniyle tam sayım yapılması hedeflenmiştir. Bu nedenle araştırma evrenini oluşturan tüm bireyler araştırma kapsamına dâhil edilmiştir. Araştırma süresi boyunca söz konusu aylarda tüm bölüm başkanlarına ulaşılmaya çalışılmış, gönüllük esasına dayalı olarak 38 bölüm başkanına ulaşılabilmiştir. 


\section{Veri Toplama Süreci}

Görüşmeler 6 Mart-29 Nisan 2020 tarihleri arasında gerçekleştirilmiştir. Bu süreçte yüz yüze görüşme sağlanamayan öğretim üyelerinin, görev yaptıkları üniversitelerin web sitelerinden maillerine ulaşlarak mülakat formu gönderilmiştir. 25 öğretim üyesinden geri dönüş sağlanmıştır. Geri dönüş sağlamayan öğretim üyelerine 4 kez daha mail atılmasına rağmen herhangi bir geri dönüş sağlanamamıştır. 9 öğretim üyesi ile yüz yüze görüşme, 4 öğretim üyesi ile de telefonla görüşme sağlanmıştır. Toplam katıllımcı sayısı 38'e ulaşmışır. Araştırmanın literatürünün desteklenmesi için Türkiye'de gastronomi ve mutfak sanatları eğitimi veren üniversitelerin akademisyen sayılarına ulaşılmıştır. Araştırma sonucunda 406 akademisyenin Gastronomi ve Mutfak Sanatları bölümünde görev yaptı̆̆ tespit edilmiştir. 406 akademisyenin de özgeçmişleri incelenip lisans mezuniyet alanları tespit edilmiştir. Elde edilen bulgular literatür kısmına eklenerek araştırma desteklenmiştir.

\section{Literatürden Elde Edilen Bulgular}

\section{Türkiye'de gastronomi eğitimi veren kurumlar ve akademik yapıları}

Türkiye'de lisans düzeyinde gastronomi eğitimi veren kurumlara ilişkin bilgiye önceki konularda Tablo 1'de değinilmiştir. Bu başlık altında lisans düzeyinde gastronomi eğitimi veren kurumlardaki öğretim üyelerinin sayısal ve unvansal durumları hakkında bir değerlendirme yapılacaktır.

2019 yllında gastronomi ve mutfak sanatları bölümünde eğitim veren Öğr. Gör. sayıs1 74, Arş. Gör. sayıs1 92, Dr. Öğr. Üyesi sayıs1 159, Doçent sayıs1 45 ve Profesör sayısının ise 36 olduğu Tablo 2.7’de görülmektedir. Türkiye'de gastronomi ve mutfak sanatları bölümünde toplam 406 öğretim elemanı görev yapmaktadır. 2018 yılında Karaca'nın yaptığı çalışmada Dr. Öğr. Üyesi sayıs1 73, Doçent sayısı 13, Profesör sayısı 12 iken bu sayllar 2019 yllında \%59 oranında artış göstermiştir.

Tablo 1. Lisans Düreyinde Gastronomi Ĕ̈itimi Veren Ögretim Üyeleri, 2019

\begin{tabular}{|c|c|c|c|c|c|}
\hline KURUMLAR & $\begin{array}{l}\text { Öğr. } \\
\text { Gör. }\end{array}$ & Arş. Gör. & $\begin{array}{c}\text { Dr. } \ddot{O} \breve{g r} . \\
\ddot{U}_{\text {yesi }}\end{array}$ & Doçent & Profesör \\
\hline Afyon Kocatepe Üniversitesi & 2 & 1 & 1 & 2 & - \\
\hline Akdeniz Üniversitesi (Manavgat) & - & - & 2 & 1 & - \\
\hline Akdeniz Üniversitesi & - & 3 & 2 & 1 & 2 \\
\hline Alanya Alaaddin Keykubat Üniversitesi & - & - & 2 & 2 & - \\
\hline Anadolu Üniversitesi & - & 4 & 3 & 2 & - \\
\hline Ankara Hacı Bayram Veli Üniversitesi & - & 1 & 5 & 3 & 3 \\
\hline Atatürk Üniversitesi & - & 2 & 4 & - & 1 \\
\hline Balıkesir Üniversitesi & - & 5 & - & 3 & 2 \\
\hline Bolu Abant İzzet Baysal Üniversitesi & 2 & 1 & 3 & - & - \\
\hline Çanakkale 18 Mart Üniversitesi & - & 1 & 2 & - & 1 \\
\hline Dokuz Eylül Üniversitesi & - & 1 & 2 & - & 1 \\
\hline Eskişehir Osmangazi Üniversitesi & 2 & 1 & 1 & 2 & 1 \\
\hline Gaziantep Üniversitesi & 1 & 2 & 6 & - & - \\
\hline Iğdır Üniversitesi & - & - & 3 & - & - \\
\hline İskenderun Teknik Üniversitesi & - & - & 2 & 1 & - \\
\hline İstanbul Medeniyet Üniversitesi & 2 & 1 & 2 & - & - \\
\hline İzmir Katip Çelebi Üniversitesi & 1 & 2 & 1 & 2 & 1 \\
\hline Karabük Üniversitesi & - & 4 & 1 & 2 & - \\
\hline Kastamonu Üniversitesi & - & 3 & 4 & - & - \\
\hline Kurklareli Üniversitesi & - & 1 & 3 & - & - \\
\hline Kocaeli Üniversitesi & - & - & 2 & 1 & - \\
\hline Kütahya Dumlupinar Üniversitesi & 1 & - & 3 & - & - \\
\hline Mardin Artuklu Üniversitesi & - & 1 & 3 & 1 & - \\
\hline Mersin Üniversitesi & 4 & 2 & 4 & 1 & - \\
\hline Munzur Üniversitesi & 1 & 4 & 2 & 2 & - \\
\hline Necmettin Erbakan Üniversitesi & - & 2 & 4 & 1 & 1 \\
\hline Nevşehir Hacı Bektaş Veli Üniversitesi & 2 & 1 & 2 & 3 & - \\
\hline Pamukkale Üniversitesi & - & 3 & 2 & - & 1 \\
\hline Recep Tayyip Erdoğan Üniversitesi & 1 & 1 & 3 & - & - \\
\hline Sakarya Uygulamalı Bilimler Ü. & - & 4 & 1 & 2 & 2 \\
\hline Selçuk Üniversitesi & 2 & - & 3 & - & 2 \\
\hline Sivas Cumhuriyet Üniversitesi & 3 & 1 & 1 & 1 & - \\
\hline Alanya Hamdullah Emin Paşa Ü. & 3 & 1 & 3 & - & 1 \\
\hline Antalya Akev Üniversitesi & 1 & 1 & 3 & - & - \\
\hline Antalya Bilim Üniversitesi & 2 & 2 & 4 & - & 1 \\
\hline
\end{tabular}




\begin{tabular}{|c|c|c|c|c|c|}
\hline Başkent Üniversitesi & 3 & 1 & 1 & 2 & 1 \\
\hline Beykent Üniversitesi & 1 & 1 & 1 & 1 & 1 \\
\hline Beykoz Üniversitesi & & 1 & 2 & & 1 \\
\hline Doğuș Üniversitesi & 4 & 2 & 2 & - & - \\
\hline İstanbul Aydın Üniversitesi & - & 2 & 1 & - & 2 \\
\hline İstanbul Ayvansaray Üniversitesi & 1 & 1 & 2 & - & 2 \\
\hline İstanbul Gedik Üniversitesi & - & 1 & 5 & - & - \\
\hline İstanbul Gelişim Üniversitesi & - & 1 & 1 & 1 & - \\
\hline İstanbul Kent Üniversitesi & - & - & 1 & 1 & - \\
\hline İstanbul Medipol Üniversitesi & - & 1 & 1 & - & - \\
\hline İstanbul Rumeli Üniversitesi & 1 & 1 & 2 & - & 3 \\
\hline İstinye Üniversitesi & 3 & 1 & 3 & - & - \\
\hline Maltepe Üniversitesi & 1 & 2 & 2 & - & - \\
\hline Nişantaşı Üniversitesi & - & 2 & 3 & - & - \\
\hline Yeditepe Üniversitesi & 7 & - & 1 & 1 & - \\
\hline Burdur Mehmet Akif Üniversitesi & 2 & 2 & 3 & - & - \\
\hline Çanakkale Onsekiz Mart Üniversitesi & 3 & 1 & 1 & - & - \\
\hline Dokuz Eylül Üniversitesi (Seferihisar) & - & 1 & 1 & 2 & - \\
\hline Karamanoğlu Mehmet Bey Üniversitesi & - & - & 2 & - & 1 \\
\hline Osmaniye Korkut Ata Üniversitesi & - & - & 2 & - & - \\
\hline Sinop Üniversitesi & - & - & 2 & - & - \\
\hline Şırnak Üniversitesi & - & - & 3 & - & - \\
\hline Tokat Gaziosmanpaşa Üniversitesi & - & - & 2 & 1 & - \\
\hline Avrasya Üniversitesi & 3 & 1 & 2 & - & 1 \\
\hline İstanbul Bilgi Üniversitesi & 1 & 2 & 2 & - & - \\
\hline İzmir Ekonomi Üniversitesi & 8 & 1 & 1 & - & 1 \\
\hline Kapadokya Üniversitesi & - & 1 & 3 & - & - \\
\hline Özyeğin Üniversitesi & 4 & 4 & 8 & 2 & - \\
\hline Yaşar Üniversitesi & - & 1 & 1 & 1 & - \\
\hline Altınbaş Üniversitesi & 2 & 1 & 3 & - & - \\
\hline İstanbul Okan Üniversitesi & 1 & 1 & 1 & - & - \\
\hline Bahçeşehir Üniversitesi & 1 & 1 & 3 & & \\
\hline İstanbul Gelişim Üniversitesi (UBY)* & - & 2 & 2 & - & 1 \\
\hline TOPLAM & 74 & 92 & 159 & 45 & 36 \\
\hline
\end{tabular}

Kaynak: İlgili Üniversitelerin Sitelerinden Bilgiler Alinarak Tablo Oluşturulmustur.

\section{Gastronomi bölümü öğretim üyelerinin özgeçmişlerine ilişkin değerlendirme}

Bir alanın eğitim sürecinde öğretim üyelerinin bilgisi, tecrübesi, alanla ilgili donanıml oluşu eğitimin niteliği açısından oldukça önemlidir. Bu doğrultuda alanda uygulamalı ve teorik ders veren öğretim üyelerinin alanla ilgili olan yükseköğretim programlarından mezun olmaları gerekmektedir. Özellikle uygulama derslerini veren öğretim üyelerinin alanla ilişkili olmaları çok önemlidir. Çünkü alanı ile ilgili uygulamalı eğitim alan bir öğretim üyesi uygulamada daha verimli bir eğitim vermektedir. Gastronomi ve aşçlık programlarında ders veren öğretim üyelerinin gastronomi ve mutfak sanatları alanından mezun olmaları temel kriter olmalıdır. Bu kadrolar en az \%70-75 oranında gastronomi eğitimi almış öğretim üyelerinden oluşmalıdır (Karaca, 2018, s. 70).

Türkiye'de gastronomi ve mutfak sanatları alanında istihdam edilen akademisyenlerin lisans mezuniyet alanları incelendiğinde (Şekil 1); turizm mezunu (\%33) öğretim üyelerinin ağırlıklı olduğu, turizmi sırasıyla g1da mühendisliği (\%24), gastronomi (\%14), diğer meslekler (\%11), konaklama işletmeciliği $(\% 6)$, işletme (\%4), veterinerlik ve beslenme ve diyetetik (\%3), yiyecek içecek işletmeciliği $(\% 2)$ alanlarının takip ettiği görülmektedir. Gastronomi alanının oranına bakıldığında çok düşük olduğu dikkat çekmektedir. Bu sonuç doğrultusunda üniversitelerin gelecek yıllarda alan için gastronomi lisans mezuniyetine sahip kişileri kurumlarında istihdam etmesi önem arz etmektedir. Gastronomi bölümünde istihdam edilen öğretim elemanlarının lisans mezuniyet alanlarına ilişkin "diğer" olarak adlandırlan bölümler aşağıdaki gibidir: 


\begin{tabular}{|c|c|c|}
\hline$\checkmark$ & Biyoloji & $\checkmark \quad$ Türkçe Öğretmenliği \\
\hline$\checkmark$ & Süt ve Teknolojileri & $\checkmark$ Tarım Ekonomisi \\
\hline$\checkmark$ & Endüstri Mühendisliği & $\checkmark \quad$ Klasik Arkeoloji \\
\hline$\checkmark$ & Mimarlık & $\checkmark \quad$ Seramik ve Cam Tasarımı \\
\hline$\checkmark$ & Gida Teknolojileri & $\checkmark \quad$ Almanca Öğretmenliği \\
\hline$\checkmark$ & Yabanc1 Diller Eğitimi & $\checkmark \quad$ Hayvansal Üretim \\
\hline$\checkmark$ & Aile Ekonomisi ve Beslenme Eğitimi & $\checkmark \quad$ Siyaset Bilimi ve Kamu Yönetimi \\
\hline$\checkmark$ & Alman Dili ve Edebiyatı & $\checkmark \quad$ Felsefe \\
\hline$\checkmark$ & Muhasebe & $\checkmark \quad$ Çocuk Gelişimi ve Ev Yönetimi \\
\hline$\checkmark$ & Sanat Tarihi & $\checkmark \quad$ Tarih \\
\hline$\checkmark$ & Siyasal Bilimler & $\checkmark \quad$ Sistem Mühendisliği \\
\hline$\checkmark$ & İngilizce Öğretmenliği & $\checkmark \quad$ Çalışma Ekonomisi ve Endüstri İlişkileri \\
\hline$\checkmark$ & Fransız Dili Edebiyat1 & $\checkmark \quad$ Ortaöğretim Fen ve Matematik Alanları Eğitimi \\
\hline$\checkmark$ & İnsan Kaynakları & $\checkmark \quad$ Bilgisayar Öğretmenliği \\
\hline$\checkmark$ & Sermaye Piyasası & $\checkmark \quad$ Ticaret Eğitimi \\
\hline$\checkmark$ & Sosyoloji & $\checkmark \quad$ Peyzaj Mimarlığı \\
\hline$\checkmark$ & İstatistik & $\checkmark \quad$ Ziraat Mühendisliği \\
\hline$\checkmark$ & Çevre Mühendisliği & $\checkmark \quad$ İktisat \\
\hline & $\begin{array}{l}3 \% \\
6 \% \\
3 \% \\
4 \%\end{array}$ & $\begin{array}{l}\text { Turizm } \\
\text { Gastronomi } \\
\text { Yiyecek İçecek İşletmeciliği } \\
\text { Gida Mühendisliği } \\
\text { İşletme } \\
\text { Veteriner } \\
\text { Konaklama Issletmeciliği } \\
\text { Beslenme ve Diyetetik } \\
\text { Diğer }\end{array}$ \\
\hline
\end{tabular}

Şekil 1. Gastronomi ve Mutfak Sanatlar Bölümünde İstibdam Edilen Tüm Akademisyenlerin Lisans Mezuniyet Alanlar 2019 (Kaynak: YÖK Akademik, 2019; Ulusal Tez, Merkezi, 2019)

Gastronomi ve mutfak sanatları bölümünde görev yapan öğretim görevlilerinin lisans düzeyindeki mezuniyet alanlarına ilişkin bulgulara bakıldığında (Şekil 2); öğretim görevlilerinin \%27'sinin turizm, \%22'sinin gastronomi, \%14'ünün gıda mühendisliği, \%8'inin işletme alanlarından mezun olduğu görülmektedir. Gastronomi ve mutfak sanatları alanının \%14 oranında bir pay alması dikkat çekmektedir.

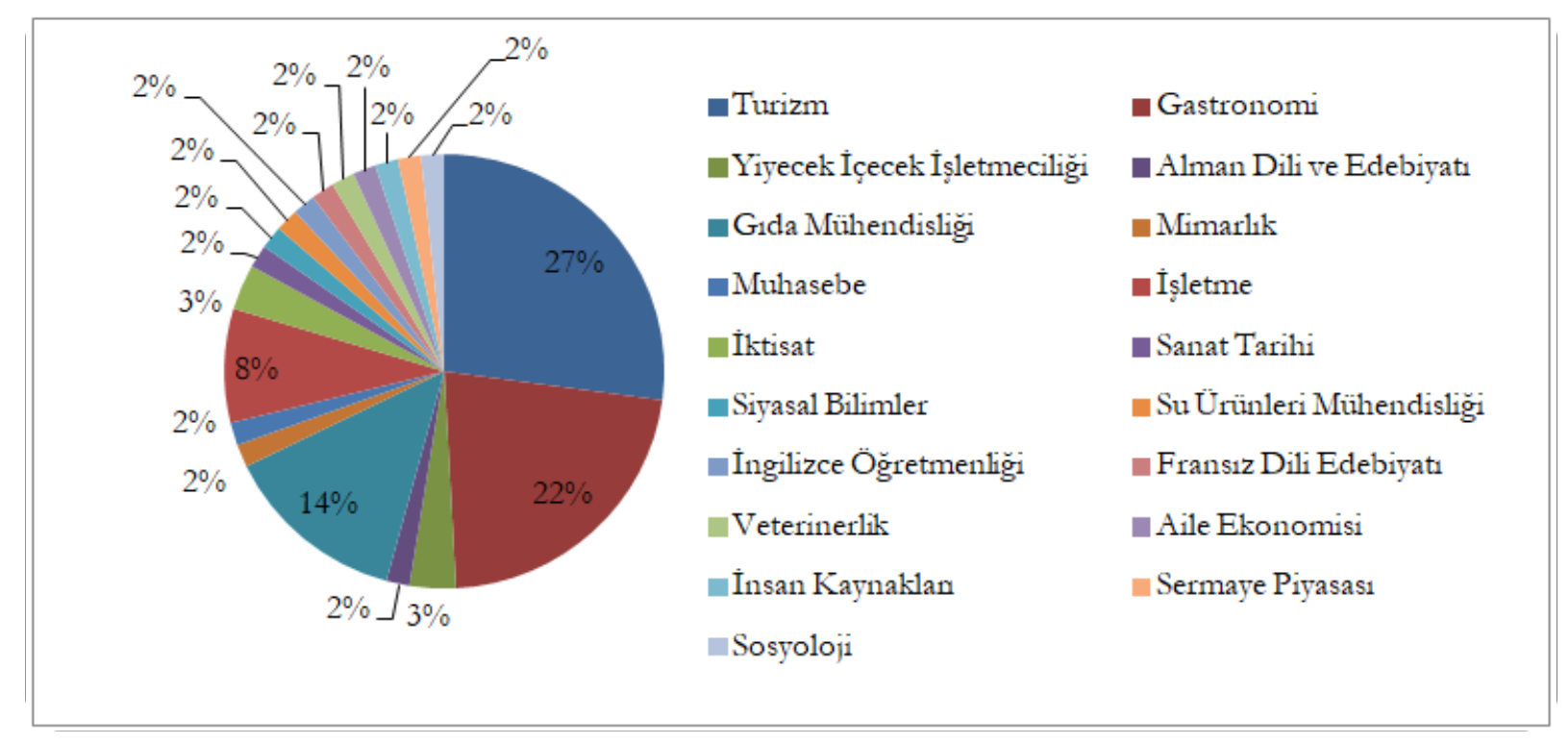


Şekil 2. Gastronomi Bölümünde İstihdam Edilen Ögretim Görevlilerinin Lisans Mequniyet Alanlar 2019 (Kaynak: YÖK Akademik, 2019; Ulusal Tez Merkezi, 2019)

Şekil 3 incelendiğinde, Gastronomi ve Mutfak Sanatları alanında görev yapan araştırma görevlilerinin \%36'sının gastronomi, \%17'sinin turizm, \%12'sinin g1da mühendisliği ve \%7'sinin yiyecek içecek işletmeciliği ve \%5'nin ise beslenme ve diyetetik ve konaklama işletmeciliği bölümlerinden mezun oldukları görülmektedir. Öğretim görevlilerinin lisans mezuniyet alanlarıyla karşılaştırıldığında araştırma görevlilerinin lisans mezuniyetlerinin gastronomi alanında daha fazla olduğu dikkat çekmektedir.

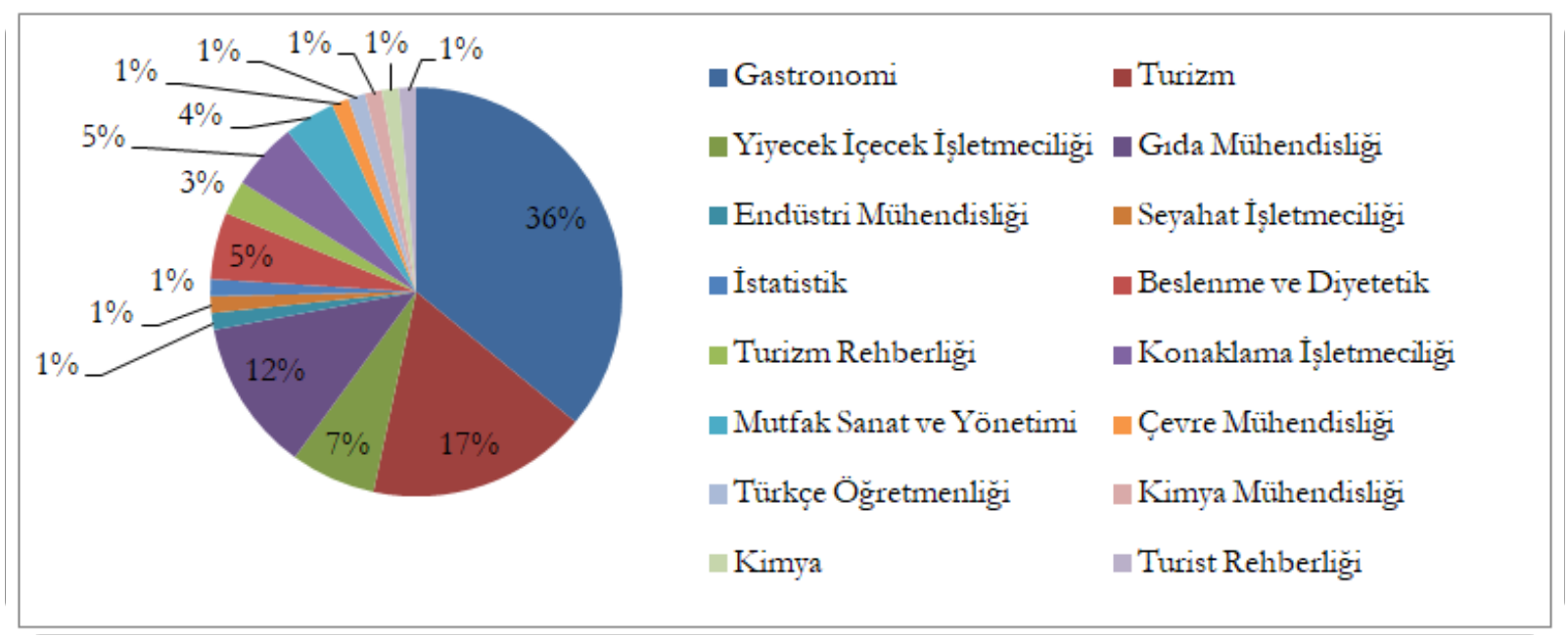

Şekil 3. Gastronomi Bölümünde Istihdam Edilen Araștırma Görevlilerinin Lisans Mequniyet Alanlarn 2019 (Kaynak: YÖK Akademik, 2019; Ulusal Tez Merkezi, 2019)

Gastronomi ve mutfak sanatları bölümünde görev yapan Doktor Öğretim Üyelerinin lisans mezuniyet alanlarının; \%34 oranında gıda mühendisliği, \%31 oranında turizm, \%7 oranında konaklama işletmeciliği, \%1 oranında gastronomi, \%3 oranında aile ekonomisi ve beslenme eğitimi, işletme, su ürünleri mühendisliği ve biyoloji olduğu Şekil 4'te görülmektedir. Doktor Öğretim Üyelerinin lisans mezuniyetlerinin sadece $\% 1$ oranında gastronomi olduğu dikkat çekmektedir. Bu durum gastronomi ve mutfak sanatları bölümünün yeni bir bölüm olmasıyla açıklanmaktadır. Gelecek yıllarda bu oran artırılmalıdır. Gastronomi bölümünde istihdam edilen öğretim görevlilerinin lisans mezuniyet alanlarına ilişkin "diğer" olarak adlandırılan bölümler aşağıdaki gibidir:

\footnotetext{
$\checkmark \quad$ Beslenme ve Diyetetik

$\checkmark \quad$ Almanca Öğretmenliği

$\checkmark$ Tarla Bitkileri

$\checkmark$ Hayvansal Üretim

$\checkmark$ Tarim Ekonomisi

$\checkmark \quad$ Siyaset Bilimi ve Kamu Yönetimi
}

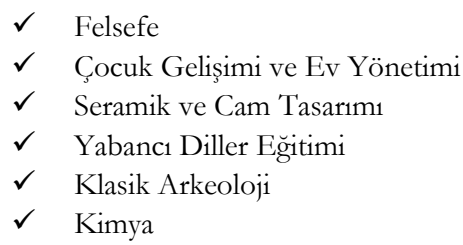

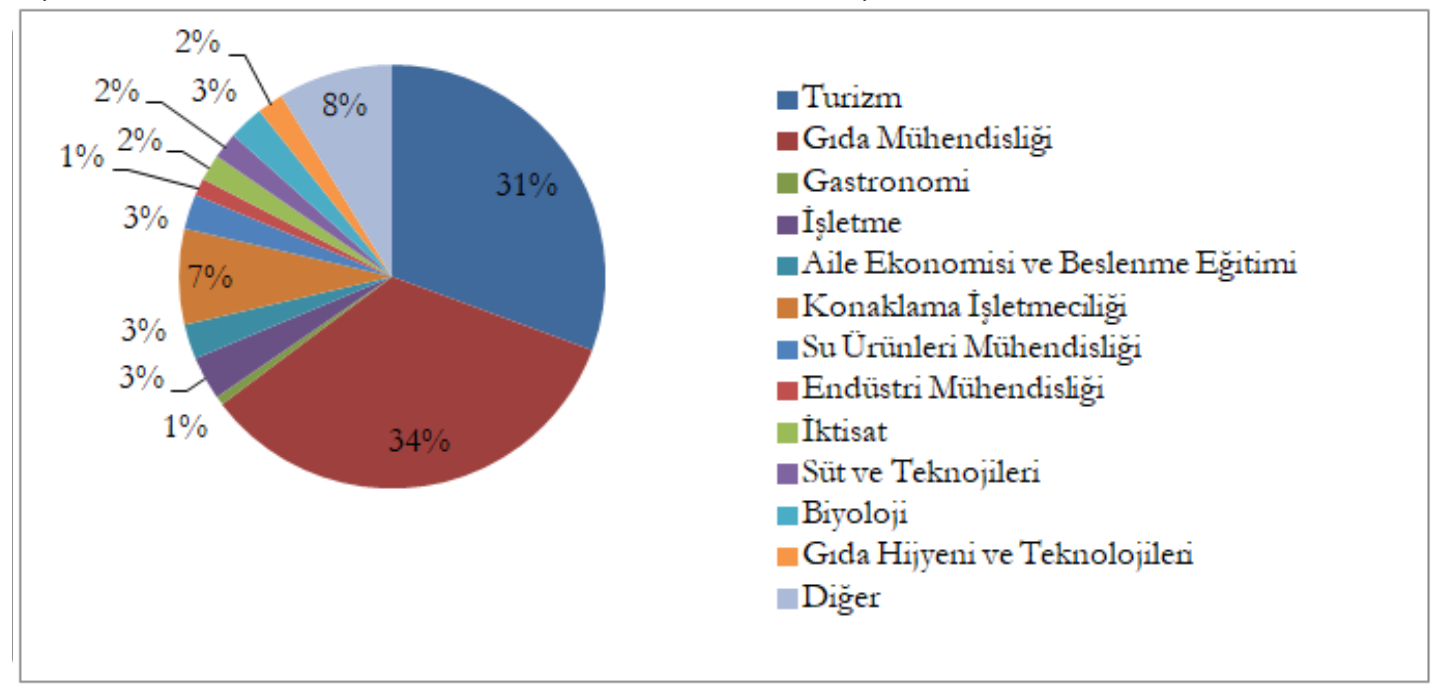


Şekil 4. Gastronomi Bölümünde İstibdam Edilen Doktor Öğretim Üyelerinin Lisans Mezuniyet Alanlar 2019

(Kaynak: YÖK Akademik, 2019; Ulusal Tez. Merkezi, 2019)

Şekil 5'deki veriler incelendiğinde; Doçent unvanına sahip öğretim üyelerinin lisans mezuniyet alanlarının $\% 43$ oranında turizm, $\% 2$ oranında gastronomi, $\% 11$ oranında gıda mühendisliği, $\% 9$ oranında konaklama işletmeciliği, \%5 oranında işletme ve aile ekonomisi ve beslenme olduğu, diğer alanların ise $\% 2$ 'lik dilimi oluşturduğu görülmektedir.

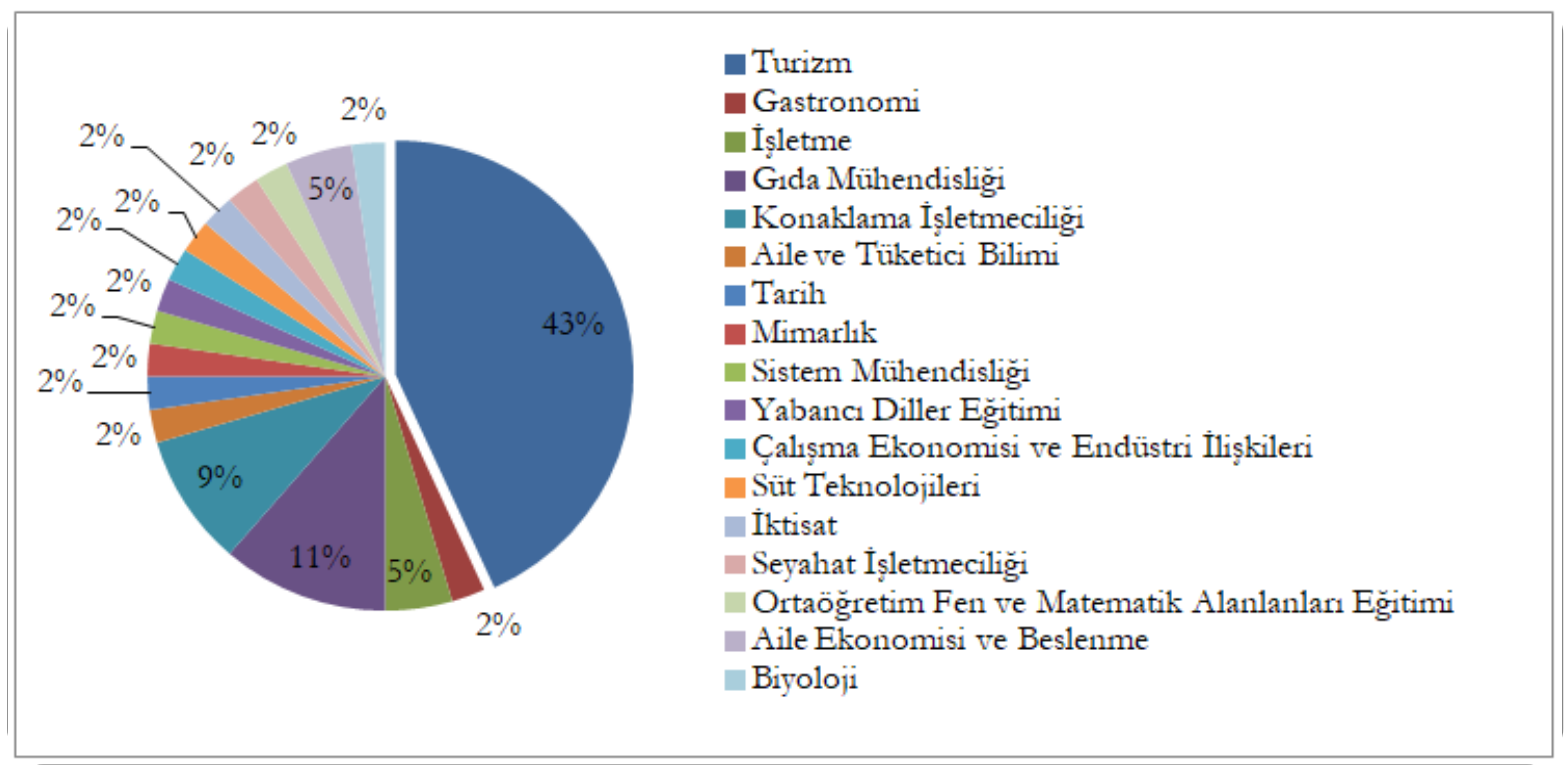

Şekil 5. Gastronomi Bölümünde İstibdam Edilen Doçent Doktorlarn Lisans Męuniyet Alanlar 2019 (Kaynak: YÖK Akademik, 2019; Ulusal Tez, Merkezi, 2019)

Gastronomi ve mutfak sanatları alanında istihdam edilen Profesör Doktor unvanına sahip akademisyenlerin lisans mezuniyet alanlarının ağıllıklı olarak; turizm (\%29) olduğu, turizmi \%19 oranla veterinerlik, \%6 oranla gıda mühendisliği ve beslenme ve diyetetik alanlarının takip ettiği Şekil 6'da görülmektedir. Burada göze çarpan gastronomi lisans mezuniyetine sahip Profesör Doktorların olmayışıdır ki bu durum daha önce de değinildiği gibi bölümün yeni bir alan olmasından kaynaklanmaktadır. Diğer bir ilginç bulgu ise \%19 oranıla veterinerlik lisans mezunu öğretim üyelerinin gastronomi bölümünde bulunmasıdır. Ancak, veterinerlik lisans mezunlarının gastronomi bölümlerinde varllğı, aşağılda sıralanan konu ve eğitimlerle ilişkilendirilebilir: Veteriner hekimlik AB mevzuatı kapsamında gıda hijyeninde tek yetkili meslektir, g1da mikrobiyolojisi, g1da kimyas1, et- Süt hijyeni ve teknolojisi, g1da mevzuatı.

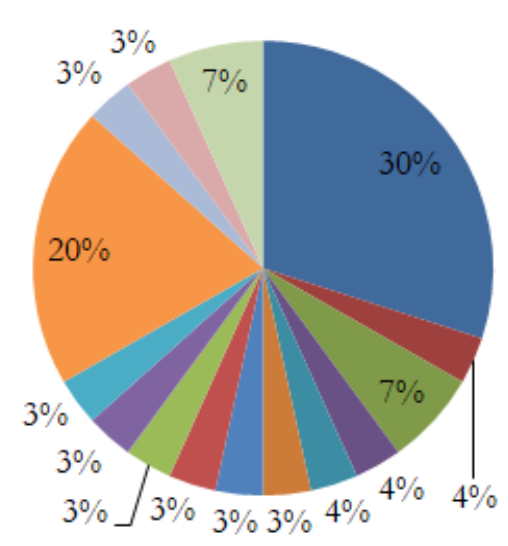

Turizm

- Gida Mühendisliği

ص Süt ve Teknolojileri

- Gida Teknolojilen

Ticaret Eğitimi

İktisat

Peyzaj Mimarlı̆̆1

Beslenme ve Diyetetik
口İsletme

• Bilgisayar Öğretmenliği

- Kimya Mühendisliği

- Biyoloji

- Gida Beslenme ve Teknolojisi

- Veteriner

Ziraat Mühendisliği 
Şekil 6. Gastronomi Bölümünde Istihdam Edilen Profesör Doktorlarn Lisans Mezuniyet Alanlar 2019 (Kaynak: YÖK Akademik, 2019; Ulusal Tez Merkezi, 2019)

Deveci vd. (2020) yılında devlet üniversiteleri ile sınırlandırılarak yapmış oldukları çalışmada Mart 2020 yılına kadar olan süreçte gastronomi ve mutfak sanatları programlarında 243 akademik personelin olduğu sonucuna ulaşılmıştır. Yine aynı çalışmada öğretim üyelerinin eğitim alanları incelenmiş ve ilk sırada turizm, ikinci sırada ise gıda mühendisliği programlarının olduğu tespitine varılmıştır. Yapılan bu çalışma ise hem devlet hem de vakıf üniversitelerini kapsamaktadır. Çalışmada 406 akademik personelin var olduğu, genel grafikte görünen Şekil 1 eğitim alanlarında ise birinci sırada turizm, ikinci sırada ise g1da mühendisliği programlarının olduğu sonucuna ulaşılmıştır. Yapılan her iki çalışmanın sonucu da birbirlerini destekleyici niteliktedir.

\section{Kat1limcilardan Elde Edilen Bulgular}

\section{Katılımcıların demografik özellikleri}

Katılımcıların \%71'inin erkek, \%47'sinin 31-40 yaş aralığında olduğu tespit edilmiştir. Katılımcıların çalıştığı kurumun sahiplik durumu değişkenine bakıldığında \%80’ini devlet üniversitesi \%20'sinin ise vakıf üniversitesi olduğu görülmektedir. Unvan değişkeni ele alındığında katılımcıların \%60’1 Doktor Öğretim Üyesi, \%29’u Doçent unvanına sahiptir. Katılımcıların \%82'sinin bölüm başkanı, \%11'inin bölüm başkan yardımcısı olduğu tespit edilmiştir. Deneyim süresine ilişkin bilgiler incelendiğinde \%34'ünün 16 y1l ve üzeri deneyime sahip olduğu görülmektedir.

Tablo 2. Katılmoularn Demografik Özelliklerine Iliskin Frekans Dăğllmı

\begin{tabular}{|c|c|c|c|}
\hline & Demografik özellik & $F$ & $\%$ \\
\hline \multirow{2}{*}{ Cinsiyet } & Kadin & 18 & 47,0 \\
\hline & Erkek & 20 & 53,0 \\
\hline \multirow{2}{*}{ Üniversite } & Devlet & 28 & 80,0 \\
\hline & Vakif & 10 & 20,0 \\
\hline \multirow{4}{*}{ Yaş } & $21-30$ & 1 & 3,0 \\
\hline & $31-40$ & 18 & 47,0 \\
\hline & $41-50$ & 12 & 32,0 \\
\hline & 51 ve üzeri & 7 & 18,0 \\
\hline \multirow{4}{*}{ Görevi } & Bölüm Başkanı & 33 & 82,0 \\
\hline & Bölüm Başkan Yardımcısı & 3 & 11,0 \\
\hline & Dekan Yardımcisı & 1 & 3,0 \\
\hline & Müdür & 1 & 4,0 \\
\hline \multirow{4}{*}{ Unvan } & Öğretim Görevlisi & 1 & 3,0 \\
\hline & Doktor Öğretim Üyesi & 23 & 60,0 \\
\hline & Doçent Doktor & 11 & 29,0 \\
\hline & Profesör Doktor & 3 & 8,0 \\
\hline \multirow{4}{*}{ Deneyim Süresi } & $3-7$ y1l & 6 & 16,0 \\
\hline & $8-11$ yll & 10 & 26,0 \\
\hline & $12-15$ yll & 9 & 24,0 \\
\hline & 16 yll ve üzeri & 13 & 34,0 \\
\hline
\end{tabular}

Katılımcıların eğitim aldıkları alana ilişkin bulgular

Bu bölümde katılımcılara gastronomi eğitimi alıp almadıklarına ilişkin bilgiler sorulmuş, evet ve hayır seçenekleri kullanılmıştır. Katılımcılardan "evet" yanıtı alındı̆̆ında, hangi alanda eğitim aldıklarına dair mesleki ölçekler sunulmuştur. Katılımcıların verdikleri cevaplar incelendiğinde \%68’i gastronomi eğitimi almadığını belirtmiştir. Evet, yanıtı verenlere "Hangi meslek alanında gastronomi eğitimi aldımı?" sorusu yöneltildiğinde gastronomi ve mutfak sanatları (K21, K30, K38), yiyecek içecek işletmeciliği (K12, K15, K19, K28, K36), aşç1lı (K8, K20), beslenme öğretmenliği (K9, K17) alanlarında eğitim aldıklar1 tespit edilmiştir.

'Gastronomi alanıla ilgili herhangi bir sertifika programına katıldınız mı?’ şeklinde yöneltilen soruya katılımcıların \%76's1 herhangi bir sertifika programına katılmadığı yanıtını vermiştir. Sertifika programına katılanlara ise sertifika aldıkları kursun konusu ve süresi, kurum adı sorulmuştur. En fazla sertifika programına sahip K34 kodlu katılımcının olduğu görülmektedir. Bu katılımc1 devlet 
üniversitesinde istihdam etmektedir. Sertifika alıp vakıf üniversitesi bünyesinde bulunan katıllımcılar ise K16, K19 ve K38'dir. Diğer kat1limcilar ise (K20, K6, K7, K24, K12) devlet üniversitelerinde çalışmaktadır. Katılımcıların verdikleri yanıtlar detaylı bir şekilde Tablo 3 ’te verilmiştir.

Tablo 3. Katılimolarn Sertifika Programı Bilgileri

\begin{tabular}{|c|c|c|c|}
\hline Kod & Kurum Adr & Kurs Adi & Kurs Süresi \\
\hline K6 & Milli Ĕ̆itim Bakanlığ1 & Ustalık Belgesi & - \\
\hline K7 & - & Yemek Stilistliği ve Fotoğrafçllık & 5 gün \\
\hline K12 & $\begin{array}{l}\text { Pirkanma Polytechnic University of Applied } \\
\text { Sciences }\end{array}$ & Erasmus Değişim Programı & 1 dönem \\
\hline K16 & & Türk Mutfağ1 kursu & 28 gün \\
\hline K19 & Kara Kuvvetleri Komutanlığı Maliye Okulu & Mutfak Hizmetleri Yönetimi & 2 ay \\
\hline & & Sıcak Mutfak, Meksika Mutfağı, & - \\
\hline K20 & & $\begin{array}{l}\text { Pastacilık, Mutfak Ekipman } \\
\text { Kullanımı, }\end{array}$ & \\
\hline & & Süt Ürünleri Üretimi & \\
\hline K24 & Mutfak Sanatları Akademisi & $\begin{array}{l}\text { Hamur Açma, Sıcak Mutfak, } \\
\text { Avrupa Mutfakları }\end{array}$ & - \\
\hline K38 & - & Yemek Stilistliği ve Fotoğrafçllık & - \\
\hline \multirow{15}{*}{ K34 } & Hyatt Corp & Serv-Safe & 1 ay \\
\hline & Cunard Cruise lines & Sea Men Executive & 15 gün \\
\hline & American Juior Culinary Team Woldcup Training & Genç aşçlık Milli Takımı Eğitimi & 2 ay \\
\hline & International Research Chefs & Culinary Science & 3 ay \\
\hline & Association & & \\
\hline & International Wine Sommeliers Guild & Master Sommelier & 2 ay \\
\hline & Culinary Institute of America & Master Sommelier & 2 ay \\
\hline & Culinary Institute of America & Culinary Boot Camp & 1 ay \\
\hline & Culinary Institute of Canada & Fermentation and Mixology & 1 ay \\
\hline & SAS Coffee Training & Sweden, Coffee Intermadiate & 5 gün \\
\hline & SAS Coffee & Master Barista & 10 gün \\
\hline & - & Rhonefeld Silver Tea Sommelier & 20 gün \\
\hline & Herra Dura (Jaliso-Mexico) & Tequila distiller certificate & - \\
\hline & $\begin{array}{l}\text { Association of Professional Engineers and } \\
\text { Geoscientists of Alberta }\end{array}$ & Peruvian Culinary Masters & - \\
\hline & Yunnan & Xing Xao Master Tea Sommelier & 1 ay \\
\hline
\end{tabular}

\section{Öğretim elemanlarının nitelik ve niceliğine ilişkin bulgular}

Öğretim elemanlarına yönelik sorular Tablo 4'te temalaştırılarak ele alınmıştır. Her bir soru grubu belirtme sıklığı ile gösterilmiştir. Bu soru grupları 38 katıllımcı ile incelenmiştir.

Tablo 4. Öğretim Elemanlarmın Niceliğine ve Niteliğine Yönelik Sorular

\begin{tabular}{|c|c|c|c|}
\hline Soru & Tema & $n$ & Katılimc1 \\
\hline \multirow{3}{*}{$\begin{array}{l}\text { Kurumunuzda gastronomi } \\
\text { bölümünde çalısan } \\
\text { ögretim elemanlarının } \\
\text { mesleki donanımları ve } \\
\text { yeterlilikleri hakkındaki } \\
\text { düşünceleriniz nelerdir? }\end{array}$} & Mesleki donanımları yeterlidir & 28 & $\begin{array}{c}\text { K19-K26-K27-K16-K13-K25-K33-K17-K20-K6- } \\
\text { K31-K32-K37-K34-K2-K9-K4-K8-K36-K21-K10- } \\
\text { K38-K5-K14-K30-K22-K7-K28 }\end{array}$ \\
\hline & Mesleki donanımları yeterli değildir & 6 & K3-K24-K12-K11-K15-K13 \\
\hline & $\begin{array}{l}\text { Kendi alaninda yeterli fakat } \\
\text { gastronomi alaninda yetersiz }\end{array}$ & 4 & K35-K29-K18-K1 \\
\hline \multirow{2}{*}{$\begin{array}{l}\text { Kurumunuzda gastronomi } \\
\text { bölümünde çalısan } \\
\text { ögretim elemanlarının } \\
\text { sayısı yeterli midir? }\end{array}$} & Sayı yeterli düzeydedir & 20 & $\begin{array}{c}\text { K16-K5-K26-K21-K27-K38-K8-K31-K32-K37- } \\
\text { K23-K25-K17-K4-K9-K2-K10-K1-K29-K24 }\end{array}$ \\
\hline & Sayı yeterli değildir & 18 & $\begin{array}{c}\text { K19-K6-K20-K14-K34-K36-K33-K22-K30-K7- } \\
\text { K28-K18-K35-K13-K15-K11-K12-K3 }\end{array}$ \\
\hline
\end{tabular}

Kurumunuzda gastronomi bölümünde çalısan ögretim elemanlarının mesleki donanımları ve yeterlilikleri hakkındaki düsünceleriniz nelerdir?’ sorusuna katılımcıların \%68'i öğretim üyelerinin mesleki donanımlarını yeterli bulduğunu dile getirmiştir. \%32'lik bir paya sahip katılımc1 ise öğretim elemanı donanımlarını yeterli bulmadığını açıklamıştır. Bunun nedeni ise genel olarak gastronomi ve 
mutfak sanatları alanında yetkin hocaların eksikliği olarak açıklanmıştır. Mesleki donanımı yeterli bulan katılımcıların açıklamaları şu şekildedir:

\begin{abstract}
- Yaken zamanda kurulan bir bölümdür. Dolayssiyla lise, lisans, yüksesek lisans ve doktora tamamen bu alanda olan ögretim eleman var mudir? Sanirm yok, ancak bu kombinasyonda lise lisans olup doktora yüksek lisansı basska alanda veya yülesek lisansı bu alanda olup lisansı başka alanda olan çok faそla ögrretim eleman mevcuttur. Turizm fakëllteleri içerisinde yer alan bir bölïmdür, dolayısyla ağrrlkklh olarak ülke genelinde de bu durum böyledir çŏğ turizm mezunlar hocalarmı bu bölïmlerde görev yapmaktadr. Disiplinler arası bir bölüm doğal olarak gida mübendisliği, sanat tasarm, beslenme gibi farkh alanlarda eğitimcilere ibtiyas duyulmaktadir. Özetle mevcut hocalarmizin farkh alanlarda uzmanliklar bulunmaktadir ve yeterlidir (K32).
\end{abstract}

- Kadroda 2 dogent, 1 Dr. Öğr. Üyesi, 2 ögretim görevlisi ve bir arasttrma görevlisi vardir. Mesleki donanum ve yeterlilikleri uygundur. Ögretim görevlilerinin ikisi de doktora eğitimine devam eden ve sektör tecrübesi olan bocalardir (K37).

- Ögretim elemanlarmmz kendi alanlarnda yetkin kişilerdir. Fakat yeni bir bölüm olmamı sebebiyle sayımız. az ve "Gastronomi ve Mutfak Sanatları" bölïmünden mezun olmus kişilere ibtiyacmmz var. Bu sebeple yeni alınacak kişilerin "Gastronomi ve Mutfak. Sanatlar" bölümü mezunu olmalarm tercih edeceğiz. (K35).

- Bölümümüzde Gastronomi ve Mutfak Sanatlar mezunu ve/veya bu alanda yükesek lisans/doktora yapan

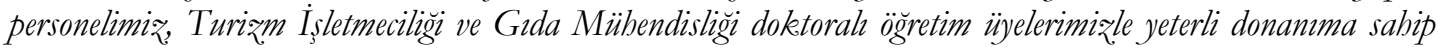
olduğumuzu düsïnïyorum (K33).

- Tüm branslardan (Gida Mühendisliugi, Gastronomi ve Mutfak Sanatlar, Beslenme ve Diyetetik) bocalarmıəla nitelikli bir eğitim yürütmekteyiz. (K31).

- Gastronomi multidispliner bir alander. Bu bilimin sosyal ve doğa bilimleri içeren derslerinin olması yansira mutfak dersleri de bulunmaktadrr. Üniversite olarak belli kriterlerimiz, mevcuttur bu kriterler mesleki donanma işaret etmektedir. Örnek olarak en az 1 ynl yurt diş tecrübesi, en az 3 adet SCI makale vb. Eğitim dilimiz İngiližce olduğu için dil yeterliklerini gösterir belge de talep edilmektedir (K26).

- Bölüm başkanmmz uluslararast işletmelerde uzun seneler aşç, sous chef ve executive chef pozisyonlarnda

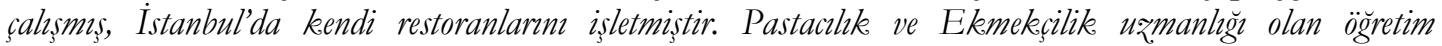

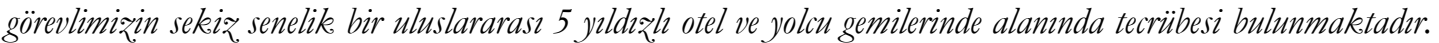
Gıda mühendisi ögretim ̈̈yemi yiyecek ve içecek işsletmeleri konusunda sok tecrübelidir. Yiyecek içecek alannda ve özellikle servis tecrübesi bulunan ögretim üyemiz ise turizm işletmeciliği ve yönetim konularnda çalşsmalarda bulunmustur (K34).

Kurumlarında öğretim elemanlarının mesleki donanımlarını yeterli bulmayan katılımcıların ise bu soru karşısında verdikleri cevaplar aşağıdaki gibidir:

- Uygulama anlaminda șimdilik yeterli olduğumuz söylenemez. Fakat iki arastrma görevlimiz doktora eğitimlerini tamamlamak üzere (Lisans, Y.Lisans ve Doktoralar Gastronomi olacak sekilde) (K12).

- Kurumumuzdaki gastronomi bölümü hocalarmn tümünün tam olarak yeterli olduklarm söyleyemem; ben seçimlerimde sektör tecrübesini de önemserim (K24).

- Yetersiz. Hem alana bâkim ögretim eleman sayısı yetersiz, hem de uygulama dersleri veren öğretim eleman sayısı çok sinurl (K15).

- Kendi alanlarnda yeterlilikleri mevcut (Grda, turizm vb.) ancak Mutfak ve Gastronomi konusunda eksiklikleri var.

Katılımcıların verdiği cevaplar doğrultusunda gastronomi ve mutfak sanatları bölümünde gerekli koşullar karşılanmadan bölümün açılmasının birçok sorunu da beraberinde getirdiği söylenebilir. $\mathrm{Bu}$ koşullara fiziki yeterliliğin eksikliği ve gastronomi alanında donanıma sahip, uygulama konusunda kendini geliştirmiş hocaların olmaması örnek gösterilebilir.

'Kurumunuzda gastronomi bölümünde çalısan ögrretim elemanlarının sayısı yeterli midir? Bu konu hakkndaki düşünceleriniz nelerdir?? sorusuna katılımcıların \%55'i sayıca yeterli olduklarını dile getirirken, \%45’i öğretim elemanı sayısının yeterli olmadığını söylemiştir. Sayıyı yeterli gören katılımcılardan alınan düşünceler aşağıda belirtilmiştir:

- Henüz 3. Simflar olduğundan yeterli. Ancak ögrenci ve ders sayısı arttıkesa yeterli olmayacaktır (K29). 
- Bölümümüzde tam ve yar zamanl olarak iki çeşit kadro vardır. Bu sebeple eksiklik bulunmamaktadır (K26).

- Yeterlidir. Farklı ve gastronominin temelini oluşturan tüm disiplinlerden hocalarmız var (K31).

- Yukarda belirttiğim gibi ögrenci sayısım fazla olmasi şubeleşmeyi zorunlu kilmaktadır. Bu durum ögretim eleman ibtiyac doğurmaktadir. Şu an bizde 3. ve 4. sinf yok, mevcut durumda idare edilebilmekte ancak bundan sonraki senelerde bu saymmn yeterli olmayacă̆ın söyleyebilirim (K32).

- Evet. Hoca sayısını çok olması avantajmıs gibi görünse de ders yükü ve uzmanlı düsünüldügünde bazı sorunlar ortaya çıabilmektedir (verilebilecek ders bulamama). Bölümde görevli ögretim elemanlarnm hem nicelik hem de nitelik bakımından yeterli olduğunu düs̈̈nüyorum (K17).

$\mathrm{Bu}$ açıklamada bulunan katılımcılar kadronun mevcut durumda yeterli olduğunu dile getirseler de ilerleyen y1llarda gastronomi ve mutfak sanatları bölümünün artacağı öngörüsüyle bölümün hoca talebini karşılayamayacağ1 kaygısını doğurmaktadır. $\mathrm{Bu}$ da gastronomi eğitimi içerisinde sorun olarak belirtilmektedir. Öğretim elemanı sayısını yeterli bulmayan katılımcıların düşünceleri ise aşağıdaki gibidir:

- Henüz çok yeni bir bölümüz ve maalesef ögretim elemanlarmı yeterli değil. Derslerde de hoca sikentısı yasamamızdan ötürü görevlendirme ile diğer bölümlerden hoca ibtiyacımız! karşılamaktayı: Bu bölüm bem teorik ve hem de uygulama gerektiren bir bölüm olduğundan ögretim eleman ibtiyacı oldukça fazladır. Üniversitelerin özellikle bu tar₹ bölümlerde daha hassas davranması ve hoca saylarm bölüm ibtiyacı doğrultusunda artırmasi gerekir (K22).

- Kesinlikle yetersiz: Öğretim görevlisi kadrolarna iẓin verilmelidir. Aş̧ı veya şef çalıştırma imkân sunulmalıdır. Tabi öncelikle mutfak ve malzeme temini yapılmalidır (K13).

- Yetersiz: Alana uygun eğitim almıs ve akademik çalısmalar olan ögretim eleman bulmakta güclük çekiyoruz. (K15).

- Ögrretim üyesi sayımı yetersiz. Toplam 3 ögretim üyesi var (2 Dr. Öğr. Üyesi, 1 Doçent). Fakülteleşme sürecini yeni tamamladı̆̆ımı için kadromuz da oluşum aşamasında (K14).

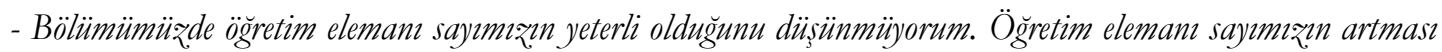
ders saatlerimizin düsmesini ve akademik çalısmalara daha fąla vakit ayurabilmemiz̧ sağlayacaktur. Önümüzdeki 1-2 sene içinde yeni ögretim elemanlarnm alınmasi planlanmaktadır. Bu kişilerin "Gastronomi ve Mutfak Sanatlar" bölümünden mezun olmuş kişiler olması gerekmektedir (K35).

- Hayır, yeterli değil. Alanında mezun ve asgari sartlar taşyan uzman hocalar bulmakta zorlanyoruz. (K30).

- Saynca yeterli değiller. Uzman ve uygulamali derslere girecek hoca bulmakta zorlanyoruz (K19).

Katılımcılar öğretim elemanı sayısındaki yetersizliğinin nedenini gastronomi ve mutfak sanatları alanında eğitim almış kişilerin eksikliği ve fakülteleşmeye gidilmeden okulların açılması olarak açıklamıştır. Eğitimin kaliteli ve eksiksiz olarak verilebilmesi için bu önemli konular üzerinde durulması gerekmektedir.

\section{Sonuç ve Öneriler}

Araştırmada Türkiye'deki 38 kurumdan bölüm başkanları ile görüşme yapılmıştır. Görüşmelerde gastronomi alanında istihdam edilen öğretim üyelerinden mesleki alanlarına ve mesleki deneyimlerine yönelik bilgiler elde edilmiştir. Bu bilgilerde gastronomi alanında eğitim almayan öğretim üyeleri olduğu tespit edilmiştir. Gastronomi alanında eğitim alanların içerisinde de beslenme, gıda mühendisliği gibi alanların olduğu görülmüştür. Bu bulgular araştırmanın literatürden elde edilen bulgularını da destekler niteliktedir.

Gastronomi ve mutfak sanatları bölümünde eğitim veren Öğr. Gör. say1s1 74, Arş. Gör. say1s1 92, Dr. Öğr. Üyesi sayısı 159, Doç. Dr. sayısı 45 ve Prof. Dr. sayısının 36 toplamda ise 406 akademisyenin var olduğu tespit edilmiştir. Türkiye'de gastronomi ve mutfak sanatları alanında istihdam edilen tüm akademisyenlerin lisans mezuniyet alanları genel olarak incelendiğinde; turizm mezunu (\%33) turizmi ise sırasılla gıda mühendisliği (\%24), gastronomi (\%14), konaklama işletmeciliği (\%6), işletme (\%4), veterinerlik ve beslenme ve diyetetik (\%3), yiyecek içecek işletmeciliği (\%2) alanlarının takip ettiği sonucuna ulaşılmıştır. Gastronomi lisans mezuniyetine sahip olan öğretim üyesinin payı sadece \%14 olması dikkat çekmektedir. Katılımcılardan alınan yorumlar da bu bulguyu desteklemektedir. Bölümde gastronomi bölümü lisans mezuniyetine sahip öğretim elemanlarına ihtiyacın olduğu da dile getirilmiştir. 
Öğretim görevlileri \%22, araştırma görevlileri \%36, doktor öğretim üyeleri \%1, doçent doktorların ise $\% 2$ oranında gastronomi lisans mezuniyetine sahip olduğu literatürden elde edilen bulgulardan tespit edilmiştir. Profesör doktor unvanına sahip öğretim üyelerinin hiçbirinin gastronomi lisans mezuniyet alanına sahip olmayışı araştırma da dikkat çeken bir diğer husustur. Profesörlerin lisans mezuniyet alanlarının ağırlıklı olarak turizm olduğu tespit edilmiştir. Bu durum gastronomi alanında doktora programlarının günümüzde az sayıda olmasıyla açıklanabilir.

Çalışmada öğretim elamanlarının nicelik ve niteliğine yönelik durumlarının belirlenmesi için katılımcılardan görüşler alınmıştır. Gastronomi eğitiminde uygulamalı bir eğitim modeli bulunmaktadır. Bunun için nitelikli bir öğretim elamanı gastronomi ve mutfak sanatları eğitiminin sürdürülebilirliği için önem teşkil etmektedir. Katılımcılardan alınan cevaplar da bu kanıyı destekler niteliktedir. Gastronomi eğitiminin popülerliğinden etkilenen kurumlar her yıl çok fazla sayıda öğrenci alımı yapmaktadır. Bu artış ögretim elamanlarına ihtiyacı da beraberinde getirmektedir. Her yıl artan öğrenci sayısına oranla öğretim elamanına da ihtiyaç artmaktadır. Gastronomi ve mutfak sanatları eğitimi veren kurumlar nitelikli öğretim elamanı bulmada zorluk çekmektedir. Katılımcılar bu durumu gastronomi eğitiminin sorunu olarak dile getirmektedir. Bu sorunun ortadan kaldırılması için hem nicelik hem de nitelik olarak öğretim elamanlarına ihtiyaç duyulmaktadır. Gastronomi ve mutfak sanatları gibi çok disiplinli bir alan, günümüzde akademik kadro sorunları yaşamaktadır. 2015 y1lında gerçekleştirilen "Gastronomi Ë̆itimi Arama Konferansı" sonuçlarında da akademik kadro sorunlarının olduğu belirtilmektedir (Öney, $2016 \mathrm{~s}$. 200).

Gastronomi eğitimi başlığı altında birçok çalışma bulunmaktadır. Brown (2005) ve Miles (2007') gastronomi eğitiminin tarihsel gelişimi üzerine bir araştırma gerçekleştirmiştir. Wollin ve Gravas (2001), Hu ve diğerleri (2007), Müller ve diğerleri (2009) gastronomi ve mutfak sanatları eğitiminin müfredatına ilişskin bir araştırma yapmıştır. Güdek ve Boylu, (2017) ise gastronomi eğitimi alan öğrenciler üzerine bir çalışma gerçekleştirmiştir. Çarbuğa, Aydın, Sormaz ve Yılmaz (2018) gastronomi eğitimi veren eğitim kurumları üzerine bir araştırma yapmış ve Türkiye'de verilen gastronomi eğitiminde ders sayısının fazla olduğu sonucuna ulaşılmıştır. Sezen (2018) gastronomi eğitiminin mevcut durumu üzerine çalışma yapmış ve gastronomi giriş derslerinin vakıf üniversitelerinde ve güzel sanatlar fakültelerinde daha fazla verildiği, soğuk mutfak derslerinin $\% 80$ 'i devlet üniversitelerinde, $\% 40$ '1 ise vakıf üniversitelerinde verildiği sonucuna varılmıştır. Deveci vd. (2020) gastronomi alanındaki akademik personelin eğitim profili incelenmiş ve akademik personelin mezuniyet alanlarında en fazla turizm ve gıda mühendisliği bölümlerinin olduğu sonucuna varılmıştır. Demirci vd. (2020) gastronomi eğitiminin değerlendirilmesi üzerine yapmış oldukları çalışmada akademisyenlerin 17 farklı alandan mezun olduğu sonucuna ulaşılmıştır. Akademisyenlerin lisans mezuniyet alanlarının araştırıldığı bu çalışma da ise gastronomi alanındaki akademisyenlerin 46 farklı alandan mezun olduğu tespit edilmiştir. Gastronomi ve mutfak sanatları eğitimi temel alınarak yapılan çalışmalarda eğitimin farklı boyutları incelenmiştir. Bu çalışma da ise gastronomi eğitimindeki istihdam yapısı araştırlmıştır. Alanda istihdam edilen öğretim üyelerinin mezuniyet alanlarının somut veriler halinde ortaya konulması, literatüre katkı sağlaması ve ilerleyen yıllarda öğretim üyesi alımlarında fikir oluşturması açısından önem arz etmektedir. Katıllımcılardan elde edilen ve literatürden derlenen bilgiler doğrultusunda aşağıdaki öneriler sunulmuştur:

- Gastronomi eğitimi verecek olan kurumların gerekli insan kaynağını bulmadan, uygulama için gerekli araç gereçleri temin etmeden ve fiziki altyapı olanaklarını sağlanmadan gastronomi bölümünü açmaması önem teşkil etmektedir.

- Akademik personel alımlarında, gastronomi eğitiminin daha verimli olması için gastronomi bölümü ve ilgili alanlardan öğretim elemanı istihdamı yapılmalıdır.

- İlerleyen yıllarda gastronomi ve mutfak sanatları eğitiminin istihdam yapısına yönelik benzer çalışmalar yapılabilir. Bu sayede farklı alanlardaki istidam durumunun devam edip etmediğinin karşılaştırılmalı analizi gerçekleştirilebilir.

- Gastronomi ve mutfak sanatları alanında istihdam edilen öğretim üyelerinin mesleki geçmişlerine yönelik nitel bir çalışma da gerçekleştirilebilir.

- Araştırma yapıllırken bazı üniversitelerin sitesinde öğretim elemanlarının bilgilerine ulaşılamamıştır. Üniversitelerin sitesinde öğretim elemanlarına ilişkin özgeçmişlerinin bulundurulması benzer çalışmalar, öğrenciler ve alana ilgi duyanlar için önem arz etmektedir.

\section{Etik Beyan}


"Gastronomi ve Mutfak Sanatları Eğitiminde İstihdam Yapısına İlişkin Bir Araştırma” başlıklı çalışmanın yazım sürecinde bilimsel kurallara, etik ve alıntı kurallarına uyulmuş; toplanan veriler üzerinde herhangi bir tahrifat yapılmamış ve bu çalışma herhangi başka bir akademik yayın ortamına değerlendirme için gönderilmemiştir. Sakarya Uygulamalı Bilimler Üniversitesi Rektörlüğü Etik Kurulu'ndan 18/02/2021 tarih ve 02 no'lu toplantısında etik kurul izni de alınmıştır.

\section{Kaynakça}

Aksoy, M., ve Şahin, A. (2017). Yiyecek içecek eğitiminde gastronomi ve mutfak sanatları ile kulinoloji programlarına dair bir karşılaştırma. Gaæ̌i Üniversitesi Sosyal Bilimler Dergisi, 5(12), 7-20.

Arslanhan, Y. (2019). Gastronomi ve mutfak sanatlar mezunlarnm sektördeki durumu ve almıs olduklar eğitimden memnuniyet düzeyleri (Yüksek Lisans Tezi). Bolu Abant İzzet Baysal Üniversitesi Sosyal Bilimler Enstitüsü. Bolu.

Aydemir, D. A. (2018). Gastronomi ve mutfak sanatlar eğitimi alan üniversite ögrencilerinin kariyer beklentileri: lisans ögrencilerine yönelike bir araştrma (Yüksek Lisans Tezi). Nevşehir Hacı Bektaş Veli Üniversitesi Sosyal Bilimler Enstitüsü, Nevşehir.

Brown, J. N. (2005). A brief history of culinary arts education in america. Journal of Hospitality \& Tourism Education, 17(4), 47-54.

Çarbuğa, Ü., Aydın, M., Sormaz, Ü. ve Yılmaz, M. (2018). Gastronomi eğitimi veren yükseköğretim kurumlarının uygulamalı meslek derslerinin değerlendirilmesi. Erişim adresi: http://sutsad.selcuk.edu.tr/index.php/sutsad/article/view/209

Demirci, B., Sarıkaya, G. S. ve Erol, E. (2020). Türkiye'de gastronomi ve mutfak sanatları eğitiminin değerlendirilmesi. Türk Turižm Araştrmalar Dergisi, 4(4): 3311-3324.

Deveci, B., Deveci, B., Aymankuy, Y. ve Aymankuy, Ş. (2020). Gastronomi ve mutfak sanatları bölümü akademik personelinin eğitim profili: Devlet üniversiteleri üzerine bir araştırma. Türk Turiz̧m Arasttrmalar Dergisi, 4(3), 2506-2526.

Görkem, O. ve Sevim, B. (2016). Gastronomi eğitiminde geç mi kalındı acele mi ediliyor? Elektronik Sosyal Bilimler Dergisi, 15(58), 977-988.

Güdek, M. ve Boylu, Y. (2017). Türkiye'de yükseköğretim düzeyinde gastronomi eğitimi alan öğrencilerin beklenti ve değerlendirmelerine yönelik bir araştırma. Journal of Tourism and Gastronomy Studies, 5(4), 489-503.

Hu, M., Chen, L. ve Lin, L. (2007). The comparative study of the culinary curriculum between taiwan and USA. Journal of Culinary Science \& Technology, 5(2- 3), 93-107.

Karaca, E. (2018). Dünya genelindeki yükesekögrretim kurumlarnda verilen gastronomi ögreniminin karşılaștrrlmal analizi (Yüksek Lisans Tezi). Sakarya Üniversitesi Sosyal Bilimler Enstitüsü. Sakarya.

Kurnaz, A., Babür, E. ve Kurnaz, H. A. (2018). Gastronomi eğitiminde bir sosyal sorumluluk projesi örneği: Mengen ulusal aşçılık kampı. Uluslararası Toplum Araștırmalar Dergisi, (8) 1-17.

Miles, R. (2007). Culinary education: past, present practice and future direction. international chree annual conference. ss.2 66-271. International CHRIE, Texas.

Milli Ĕgitim Bakanlığ1 (2019). http://mtegm.meb.gov.tr Erişim Tarihi: 05.01.2019.

Müller, K., VanLeeuwen, D., Mandabach, K. ve Harrington, R. (2009). The effectiveness of culinary curricula: a case study, international. Journal of Contemporary Hospitality Management, 21(2), 167-178.

Öney, H. (2016). Gastronomi eğitimi üzerine bir değerlendirme. Selçuk Üniversitesi Sosyal Bilimler Enstitiisü Dergisi, 35, 193-203.

ÖSYM (2019). https://dokuman.osym.gov.tr/pdfdokuman/2019/YKS/tablo3_06082019.pdf. Erişim Tarihi: 07.01.2019.

ÖSYM (2019). https://dokuman.osym.gov.tr/pdfdokuman/2019/YKS/tablo3_06082019.pdf. Erişim Tarihi: 07.01.2019.

Öztürk, Y. ve Görkem, O. (2011). Mutfak dalı öğrencilerinin mesleki yeterliklerinin değerlendirilmesi: otelcilik ve turizm meslek lisesi öğrencilerine yönelik bir Uygulama. Ișletme Arașttrmalar Dergisi 3/2 (2011) 69-89.

Şengül, S. (2019). Gastronomi eğitimi ve gastronomide kariyer. Sarışı, M., (Edt.). Tüm yönleriyle gastronomi bilimi (ss. 169-186), Ankara: Detay Yaylncllk.

Ulusal Tez Merkezi (2019). https://tez.yok.gov.tr/UlusalTezMerkezi/ Erişim Tarihi: 08.01.2019.

Wollin, M. ve Gravas, S. (2001). A proposed curriculum and articulation model for two-year degree programs in culinary arts. Journal of Hospitality \& Tourism Education, 13(2), 47-54.

YÖK Akademik Arama (2019). https://akademik.yok.gov.tr/AkademikArama/ Erişim Tarihi: 08.01.2019. 


\section{EXTENDED ABSTRACT}

The concept of food and beverage is a basic need and the food and beverage industry has an important contribution to meeting this need. Food and beverage businesses that take on the task of meeting the food needs of people have to perform this service in the highest quality. Businesses need trained personnel to provide quality service. Because only the qualified, qualified and analytical thinking personnel provide efficiency and sustainability to the enterprises. Today, the concepts of food and beverage manifest themselves in the field of gastronomy. For this reason, many universities provide education under the name of gastronomy and culinary arts department. The qualification, knowledge and equipment of the manpower, which is important for the food and beverage industry, are met by gastronomy training.

In the education process of a field, the knowledge, experience and being equipped with the field are very important in terms of the quality of education. In this direction, faculty members who teach applied and theoretical courses in the field must graduate from higher education programs related to the field. Especially, it is very important that the faculty members who teach the application courses are related to the field. Because a faculty member who receives applied education in his field provides a more efficient education in practice. The graduation of the faculty members who teach in gastronomy and culinary programs should be a basic criterion. These staff should consist of at least $70-75 \%$ of the lecturers with gastronomy education (Karaca, 2018, p.70).

A theoretical and practical education model is used in gastronomy and culinary arts education. For this reason, it is of great importance that academic members with gastronomy education are employed in the department. Gastronomy and the culinary arts at the undergraduate level in Turkey to reveal the statistical data of faculty members in institutions providing training and to investigate the graduation of the faculty has adopted the main objective.

Within the scope of the research, it was aimed to make a full count, since the number of gastronomy and culinary arts department heads was accessible. For this reason, all individuals who make up the research universe are included in the scope of the research. Throughout the research period, all department heads were tried to be reached in the said months, and 38 department heads were reached on a voluntary basis.

The research was conducted talks with heads of departments from 38 institutions in Turkey. During the interviews, information about their professional fields and professional experiences was obtained from the faculty members employed in the field of gastronomy. In this information, it has been determined that there are faculty members who are not trained in the field of gastronomy. It has been observed that there are fields such as nutrition and food engineering among those who are educated in the field of gastronomy. These findings also support the information obtained in the literature part of the research.

Participants were asked to determine the quality and quantity of the lecturers in the study. There is an applied education model in gastronomy education. For this, a qualified lecturer is important for the sustainability of gastronomy and culinary arts education. The answers received from the participants also support this opinion. Institutions affected by the popularity of gastronomy education receive a large number of students each year. This increase brings the need for teaching staff. The need for lecturers also increases in proportion to the increasing number of students every year. Institutions providing gastronomy and culinary arts education have difficulty in finding qualified lecturers. Participants express this as the problem of gastronomy education. Teaching staff are needed both in terms of quantity and quality in order to eliminate this problem. A multidisciplinary field such as gastronomy and culinary arts is experiencing academic staff problems today. In the results of the "Gastronomy Education Search Conference" held in 2015, it is stated that there are academic staff problems (Öney, 2016 p.200).

There are many studies under the title of gastronomy education. Brown (2005) and Miles (2007) conducted a research on the historical development of gastronomy education. Wollin and Gravas (2001), Hu et al. (2007), Müller et al. (2009) conducted a research on the curriculum of gastronomy and culinary arts education. Güdek and Boylu (2017) conducted a study on students who received gastronomy 
education. Çarbug, Aydın, do not ask and Yilmaz (2018) gastronomy offering education and training institutions in Turkey have done a study on it has been concluded that there is a greater number of training courses in the gastronomy. Sezen (2018) studied the current situation of gastronomy education and it was concluded that gastronomy introduction courses are given more at foundation universities and fine arts faculties, $80 \%$ of cold cuisine courses are given at state universities and $40 \%$ at foundation universities. In studies based on gastronomy and culinary arts education, different dimensions of education have been examined. In this study, the employment structure in gastronomy education was investigated. It is important in terms of presenting concrete data on the graduation fields of the faculty members employed in the field, contributing to the literature and forming an opinion on the recruitment of faculty members in the following years. 